\title{
Long-chain n-3 fatty acids and inflammation: potential application in surgical and trauma patients
}

P.C. Calder
Correspondence

P.C. Calder

Institute of Human Nutrition

School of Medicine

University of Southampton

Bassett Crescent East

Southampton SO16 7PX

UK

Fax: +44-23-8059-5489

E-mail: pcc@soton.ac.uk

Presented at the XVII Annual Meeting of the Federação de Sociedades de Biologia Experimental, Salvador, BA Brazil, August 28-31, 2002.

Received September 18, 2002 Accepted December 20, 2002 ....................
Institute of Human Nutrition, School of Medicine, University of Southampton, Southampton, UK

\begin{abstract}
Lipids used in nutritional support of surgical or critically ill patients have been based on soybean oil, which is rich in the $n-6$ fatty acid linoleic acid (18:2n-6). Linoleic acid is the precursor of arachidonic acid (20:4n-6). In turn, arachidonic acid in cell membrane phospholipids is the substrate for the synthesis of a range of biologically active compounds (eicosanoids) including prostaglandins, thromboxanes, and leukotrienes. These compounds can act as mediators in their own right and can also act as regulators of other processes, such as platelet aggregation, blood clotting, smooth muscle contraction, leukocyte chemotaxis, inflammatory cytokine production, and immune function. There is a view that an excess of $\mathrm{n}-6$ fatty acids should be avoided since this could contribute to a state where physiological processes become dysregulated. One alternative is the use of fish oil. The rationale of this latter approach is that fish oil contains long chain n-3 fatty acids, such as eicosapentaenoic acid. When fish oil is provided, eicosapentaenoic acid is incorporated into cell membrane phospholipids, partly at the expense of arachidonic acid. Thus, there is less arachidonic acid available for eicosanoid synthesis. Hence, fish oil decreases production of prostaglandins like $\mathrm{PGE}_{2}$ and of leukotrienes like $\mathrm{LTB}_{4}$. Thus, $\mathrm{n}-3$ fatty acids can potentially reduce platelet aggregation, blood clotting, smooth muscle contraction, and leukocyte chemotaxis, and can modulate inflammatory cytokine production and immune function. These effects have been demonstrated in cell culture, animal feeding and healthy volunteer studies. Fish oil decreases the host metabolic response and improves survival to endotoxin in laboratory animals. Recently clinical studies performed in various patient groups have indicated benefit from this approach.
\end{abstract}

Key words

- Polyunsaturated fatty acid

- Fish oil

- Inflammation

- Eicosanoid

- Cytokine

- Critical illness

\section{Introduction}

The lipids contained in emulsions used in nutritional support of surgical or critically ill patients have traditionally been based on soybean oil, which is rich in the n- 6 fatty acid linoleic acid (18:2n-6). Nutritional support has traditionally been aimed at supplying substrates to meet energy demands and providing building blocks for wound healing and tissue repair, in the process helping to prevent body wasting. Surgical and critically ill patients may be at risk of compromised immunity, resulting in decreased resistance 
to infection. Furthermore, it is now realised that some patients show an early hyperinflammation that might be damaging to the host. Thus, nutritional support is now aimed at providing substrates to support the immune system and nutrients (and other factors) that can modulate the inflammatory state. It is in these two areas that the fatty acids found in lipid emulsions are thought to offer great opportunity for improvement in patient outcome.

\section{Polyunsaturated fatty acids and inflammation}

\section{Biosynthesis of polyunsaturated fatty acids}

Fatty acids are often referred to by their common names, but are more correctly identified by a systematic nomenclature (Table 1). This nomenclature indicates the number of carbon atoms and the number and position of double (unsaturated) bonds in the chain (see Figure 1). It is the position of the first double bond in the hydrocarbon chain that is indicated by the $n-7, n-9, n-6$ or $n-3$ part of the shorthand notation for a fatty acid. Note that n-6 and n-3 are sometimes referred to as omega- 6 and omega-3.

There are two main families of polyunsaturated fatty acids (PUFAs), the n-6 (or omega-6) and the n-3 (or omega-3) families. Although mammals are able to synthesise saturated fatty acids from nonfat precursors and unsaturated fatty acids of the n-9 and n-7 series, they lack the delta-12 and delta15 desaturase enzymes (found in most plants) for insertion of a double bond at the n- 6 or n-3 position (Figure 1). Thus, mammalian cells cannot synthesise n- 6 or n-3 PUFAs de novo. The n- 6 and n-3 fatty acids are essential substrates for many of the major regulatory lipids in the body and as they cannot be synthesised in the body, the body must obtain them from the diet. The commonly consumed PUFAs are linoleic acid (18:2n-6) and $\alpha$-linolenic acid (18:3n-3). Once consumed these fatty acids can be converted to the longer chain, more unsaturated derivatives (Figure 2). Thus linoleic acid is converted via $\gamma$-linolenic (18:3n-6) and dihomo$\gamma$-linolenic (20:3n-6) acids to arachidonic acid (ARA; 20:4n-6) (Figure 2). Likewise, $\alpha$-linolenic acid is converted to eicosapentaenoic acid (EPA; 20:5n-3) and docosapentaenoic acid (22:5n-3) (Figure 2). There is some controversy about the extent to which docosahexaenoic acid (DHA; 22:6n-3) can be synthesised from EPA in humans. EPA, docosapentaenoic acid and DHA are termed long chain n-3 PUFAs. These fatty acids are found in oily fish and in the preparations known as fish oil.

Biological roles of polyunsaturated fatty acids

PUFAs appear to have three main biological roles. First, they are involved in regulating lipid metabolism and the processes involved in lipid transport and targeting to tissues. Examples of these activities include the inhibition of hepatic triacylglycerol synthesis by long chain $n-3$ PUFAs that contributes to their hypotriacylglycerolaemic effect and the LDL cholesterol-lowering effect of linoleic acid. Secondly, PUFAs are important components of the membranes of all cells. Here they are present in the phospholipids that typically contribute about $50 \%$ to the bulk of the membrane. The nature of the fatty acids in membrane phospholipids contributes greatly to the fluidity of the membrane and this is believed to play a role in regulating the activity of membrane proteins. Membrane phospholipids are also the source of second messenger molecules, such as diacylglycerol, phosphatidic acid, inositol-1,4,5-trisphosphate, ceramide and ARA, which are responsible for signalling events of membrane origin to the cytosol and the nucleus in order to promote appropriate cellular responses, and of extracellular signal- 
ling molecules such as platelet-activating factor. Thirdly, some PUFAs are substrates for the synthesis of bioactive molecules such as prostaglandins (PG), thromboxanes (TX) and leukotrienes (LT).

\section{Arachidonic acid as a substrate for synthesis of bioactive mediators}

The principal functional role for 20-carbon PUFAs is as substrates for synthesis of the family of bioactive mediators known as eicosanoids (PG, TX, LT, lipoxins, hydroxy-

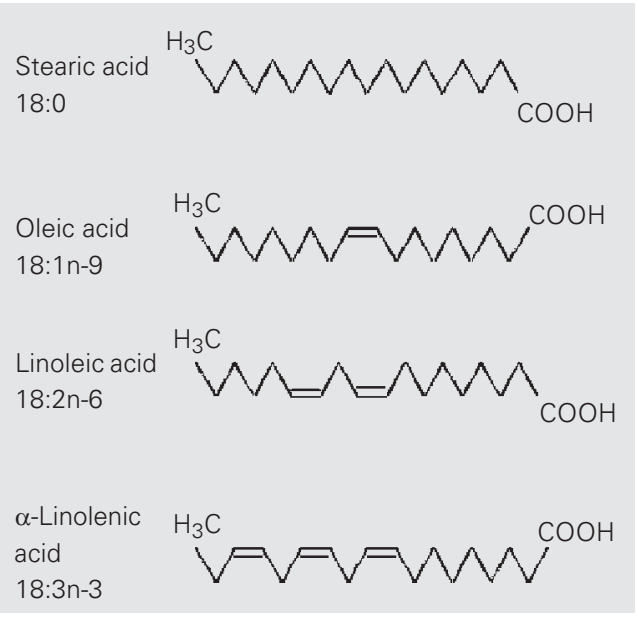

Figure 1. Structure of some fatty acids.

Table 1. Fatty acid nomenclature and sources.

\begin{tabular}{|c|c|c|c|}
\hline Systematic name & Trivial name & $\begin{array}{l}\text { Shorthand } \\
\text { notation }\end{array}$ & Sources \\
\hline Decanoic & Capric & $10: 0$ & De novo synthesis; coconut oil \\
\hline Dodecanoic & Lauric & $12: 0$ & De novo synthesis; coconut oil \\
\hline Tetradecanoic & Myristic & $14: 0$ & De novo synthesis; milk \\
\hline Hexadecanoic & Palmitic & $16: 0$ & $\begin{array}{l}\text { De novo synthesis; milk; eggs; animal fats; meat; cocoa butter; palm oil } \\
\text { (other vegetable oils contain lesser amounts); fish oils }\end{array}$ \\
\hline Octadecanoic & Stearic & 18:0 & De novo synthesis; milk; eggs; animal fats; meat; cocoa butter \\
\hline 9-Hexadecenoic & Palmitoleic & $16: 1 n-7$ & Desaturation of palmitic acid; fish oils \\
\hline 9-Octadecenoic & Oleic & $18: 1 n-9$ & $\begin{array}{l}\text { Desaturation of stearic acid; milk; eggs; animal fats; meat; cocoa butter; } \\
\text { most vegetable oils especially olive oil }\end{array}$ \\
\hline 9,12-Octadecadienoic & Linoleic & $18: 2 n-6$ & $\begin{array}{l}\text { Cannot be synthesised in mammals; some milks; eggs; animal fats; meat; } \\
\text { most vegetable oils especially corn, sunflower, safflower and soybean oils; } \\
\text { green leaves }\end{array}$ \\
\hline $9,12,15$-Octadecatrienoic & $\alpha$-Linolenic & $18: 3 n-3$ & $\begin{array}{l}\text { Cannot be synthesised in mammals; green leaves; some vegetable oils } \\
\text { especially rapeseed, soybean and linseed oils }\end{array}$ \\
\hline $6,9,12-$-Octadecatrienoic & $\gamma$-Linolenic & $18: 3 n-6$ & Synthesised from linoleic acid; borage and evening primrose oils \\
\hline 11,14,17-Eicosatrienoic & Mead & $20: 3 n-9$ & Synthesised from oleic acid; indicator of essential fatty acid deficiency \\
\hline 8,11,14-Eicosatrienoic & Dihomo- $\gamma$-linolenic & $20: 3 n-6$ & Synthesised from $\gamma$-linolenic acid \\
\hline $5,8,11,14$-Eicosatetraenoic & Arachidonic & $20: 4 n-6$ & $\begin{array}{l}\text { Synthesised from linoleic acid via } \gamma \text {-linolenic and dihomo- } \gamma \text {-linolenic } \\
\text { acids; meat }\end{array}$ \\
\hline $5,8,11,14,17$-Eicosapentaenoic & Eicosapentaenoic & $20: 5 n-3$ & Synthesised from $\alpha$-linolenic acid; fish oils \\
\hline 7,10,13,16,19-Docosapentaenoic & Docosapentaenoic & $22: 5 n-3$ & Synthesised from $\alpha$-linolenic acid via eicosapentaenoic acid \\
\hline $4,7,10,13,16,19$-Docosahexaenoic & Docosahexaenoic & $22: 6 n-3$ & Synthesised from $\alpha$-linolenic acid via eicosapentaenoic acid; fish oils \\
\hline
\end{tabular}


Figure 2. Outline of the pathway of biosynthesis of polyunsaturated fatty acids.
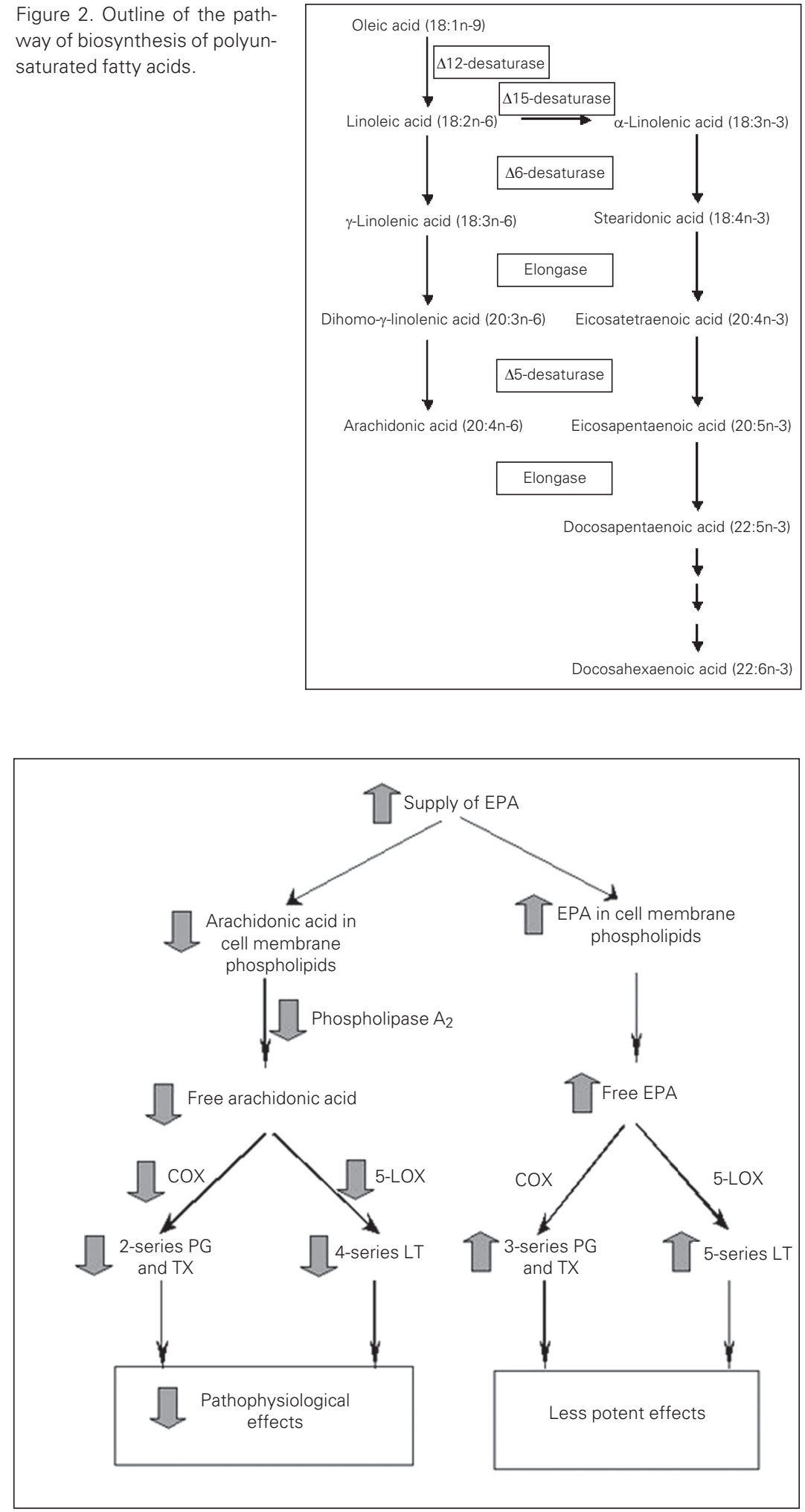

Figure 3. Basis of the anti-inflammatory effects of eicosapentaenoic acid. COX, cyclooxygenase; EPA, eicosapentaenoic acid; LOX, lipoxygenase; LT, leukotriene; PG, prostaglandin; TX, thromboxane. eicosatetraenoic acids, etc.) (Figure 3). Although several 20-carbon PUFAs are able to serve as precursors of eicosanoids, ARA is usually the principal substrate for their synthesis. This is because the membranes of most cells contain large amounts of ARA, compared with other potential eicosanoid precursors (including EPA). ARA in cell membranes can be mobilised by various phospholipase enzymes, most notably phospholipase $\mathrm{A}_{2}$, and the free ARA can subsequently act as a substrate for the enzymes that synthesise eicosanoids (Figure 3). Metabolism of ARA by cyclooxygenase (COX) enzymes gives rise to the 2 -series $\mathrm{PG}$ and $\mathrm{TX}$ (Figure 3). There are two isoforms of COX: $\mathrm{COX}-1$ is a constitutive enzyme and COX-2 is induced in inflammatory cells as a result of stimulation and is responsible for the markedly elevated production of PG which occurs upon cellular activation. Metabolism of ARA by the 5-lipoxygenase (5-LOX) pathway gives rise to hydroxy and hydroperoxy derivatives and the 4-series LT, $\mathrm{LTA}_{4}, \mathrm{~B}_{4}$, $\mathrm{C}_{4}, \mathrm{D}_{4}$ and $\mathrm{E}_{4}$ (Figure 3 ).

Eicosanoids act as mediators in their own right (e.g., $\mathrm{PGE}_{2}$ causes pain), modify the responses to other mediators (e.g., $\mathrm{PGE}_{2}$ potentiates the pain caused by bradykinin) and act as regulators of other processes, such as platelet aggregation, blood clotting, smooth muscle contraction, leukocyte chemotaxis, inflammatory cytokine production, and immune function. The effects of eicosanoids on inflammation and immunity have attracted much attention in recent years (for reviews, see Refs. 1-3). The effects of $\mathrm{PGE}_{2}$ and $\mathrm{LTB}_{4}$ have been studied most widely. $\mathrm{PGE}_{2}$ has a number of proinflammatory effects including inducing fever, increasing vascular permeability and vasodilation and enhancing pain and edema caused by other agents such as bradykinin and histamine. $\mathrm{PGE}_{2}$ suppresses production of TNF- $\alpha$ and IL- 1 and so in these respects is anti-inflammatory. $\mathrm{PGE}_{2}$ suppresses lymphocyte proliferation and 
natural killer cell activity and inhibits production of IL-2 and IFN- $\gamma$, and so in these respects $\mathrm{PGE}_{2}$ is immunosuppressive. $\mathrm{PGE}_{2}$ also promotes IgE production by $\mathrm{B}$ lymphocytes; IgE is a mediator of allergic inflammation. $\mathrm{TXA}_{2}$ promotes platelet aggregation, leukocyte adhesion, and smooth muscle contraction. $\mathrm{LTB}_{4}$ increases vascular permeability, enhances local blood flow, is a potent chemotactic agent for leukocytes, induces release of lysosomal enzymes, enhances generation of reactive oxygen species, and enhances production of TNF- $\alpha$, IL-1, and IL-6. In all of these respects $\mathrm{LTB}_{4}$ is proinflammatory. In inflammatory conditions increased rates of production of ARA-derived eicosanoids are found and elevated levels of certain eicosanoids are found in blood and tissues from patients with inflammatory disorders, burns and critical illness. Interestingly, recent studies have shown that $\mathrm{PGE}_{2}$ inhibits 5-LOX, so preventing the generation of the inflammatory 4-series LT (4). Furthermore, $\mathrm{PGE}_{2}$ was found to induce generation of the 15-LOX product lipoxin $\mathrm{A}_{4}$, a known inflammation "stop signal" (4). Thus, although $\mathrm{PGE}_{2}$ does possess distinct proinflammatory actions, it is involved in mediating the resolution of inflammation through effects on the generation of other eicosanoids.

\section{Alternatives to $\mathbf{n}-\mathbf{6}$ polyunsaturated fatty acids for use in artificial nutrition}

Although most standard lipid emulsions for use in surgical or critically ill patients are based upon soybean oil, there is a view that an excess of n-6 PUFAs should be avoided since this could contribute to a state where physiological processes become dysregulated (e.g., 5). However, while there are some studies that indicate provision of emulsions rich in n-6 PUFAs is detrimental to the host (e.g., impairing immune function), there are other, similar, studies showing no such impairment (see 6 for references). Neverthe- less, nutritional support regimens containing alternative types of fatty acids are being sought. One alternative is to reduce the amount of n-6 PUFA-containing oil by partly replacing it with medium chain triglycerides (MCT; i.e., triacylglycerols containing fatty acids of carbon chain length 6 to 12). This approach will not be further discussed here. A second approach is to replace part of $n-6$ PUFA-rich oil in emulsions designed for parenteral use with olive oil, which is rich in the n-9 monounsaturated fatty acid oleic acid (18:1n-9; Figure 1). This approach is currently under investigation and will not be discussed here. The third approach is to replace part of n-6 PUFA-rich oil with fish oil, which contains long chain n-3 PUFAs.

\section{Eicosapentaenoic acid as an arachidonic acid antagonist}

When fish oil is provided, EPA is incorporated into cell membrane phospholipids, partly at the expense of ARA. Thus, there is less ARA available for eicosanoid synthesis (Figure 3). In addition, EPA inhibits the oxidation of ARA by COX (7). Hence, fish oil decreases production of prostaglandins like $\mathrm{PGE}_{2}$, of thromboxanes like $\mathrm{TXA}_{2}$ and of leukotrienes like $\mathrm{LTB}_{4}$. This has been demonstrated many times in cell culture, animal feeding and healthy volunteer studies. Thus, n-3 PUFAs can potentially reduce platelet aggregation, blood clotting, smooth muscle contraction, and leukocyte chemotaxis, and can modulate inflammatory cytokine production and immune function (Figure 3).

In addition to inhibiting metabolism of ARA, EPA is able to act as a substrate for both COX and 5-LOX (Figure 3), giving rise to derivatives which have a different structure to those produced from ARA (i.e., 3series PG and TX and 5-series LT). Thus, the EPA-induced suppression in the production of ARA-derived eicosanoids is accompa- 
nied by an elevation in the production of EPA-derived eicosanoids (e.g., 8-11). The eicosanoids produced from EPA are considered to be less biologically potent than the analogues synthesised from ARA (e.g., $12,13)$, although the full range of biological activities of these compounds has not been investigated. The reduction in generation of ARA-derived mediators which accompanies fish oil consumption has led to the idea that fish oil is anti-inflammatory (Figure 3). Additionally, recent studies suggest that metabolism of EPA by COX gives rise to a novel series of eicosanoids that are antiinflammatory in nature (14).

The isolated, perfused rabbit lung has been used as a model to study the pathophysiological effects of ARA- and EPAderived eicosanoids. Infusion with Escherichia coli hemolysin was shown to induce vasoconstriction/hypertension, mediated by $\mathrm{TXB}_{2}$, and vascular permeability/leakage, mediated by 4-series LT (15). Inclusion of free ARA in the perfusate increased $\mathrm{TXB}_{2}$ and 4-series LT generation, arterial pressure and vascular leakage $(15,16)$. In contrast, inclusion of EPA decreased $\mathrm{TXB}_{2}$ and 4series LT generation, arterial pressure and vascular leakage and increased generation of $\mathrm{TXB}_{3}$ and 5-series LT (15). Perfusion of isolated rabbit lungs with a fish oil-containing emulsion markedly attenuated the vascular inflammatory reaction (hypertension) induced by calcium ionophore (17). Compared with perfusion with a soybean oil-rich emulsion, fish oil decreased the concentration of $\mathrm{LTC}_{4}$ in the perfusate by $>50 \%$ and increased the concentration of $\mathrm{LTC}_{5}$ from barely detectable $(<10 \mathrm{pg} / \mathrm{ml})$ to a concentration very similar to that of $\mathrm{LTC}_{4}$ (approximately 150 $\mathrm{pg} / \mathrm{ml}$ ) (17). These observations indicate that n-3 PUFAs can significantly inhibit the acute inflammatory responses induced, or at least marked, by production of ARA-derived eicosanoids. n-3 Polyunsaturated fatty acids and inflammatory cytokines

Although the action in antagonising ARA metabolism is a key anti-inflammatory effect of n-3 PUFAs, these fatty acids have other effects that might occur downstream of altered eicosanoid production or might be independent of this (see 18,19). Cell culture, animal feeding and healthy human volunteer studies have demonstrated that n-3 PUFAs can decrease the production of TNF- $\alpha$, IL-1ß, IL-6, and tissue factor by stimulated monocytes, macrophages and/or endothelial cells (see 19 for a review). Endotoxin was used most often as the cell stimulus in these studies. A recent study reported that ARA alone can induce the production of TNF- $\alpha$, IL- $1 \alpha$ and IL- $1 \beta$ by a cultured human osteoblast-like cell line (20). EPA (or oleic acid) alone did not induce production of these cytokines and EPA (and oleic acid) inhibited by at least $50 \%$ ARA induction of the cytokines (20). In similar studies, n-3 PUFAs inhibited the expression of TNF- $\alpha$, IL- $1 \alpha$ and IL- $1 \beta$ messenger RNA by cultured explants of bovine chondrocytes or human osteoarthritic cartilage, and prevented further IL-1 induction of these messenger RNAs $(21,22)$.

\section{Fish oil and animal models of endotoxemia} and sepsis

The importance of a hyperinflammatory response, characterised by overproduction of TNF- $\alpha$, IL-1 $1 \beta$, IL- 6 and IL- 8 , in the progression of trauma patients towards sepsis is now recognised. Enhanced production of ARA-derived eicosanoids such as $\mathrm{PGE}_{2}$ is also associated with trauma and burns. The inflammatory effects of infection can be mimicked by administration of endotoxin, which causes an elevation of circulating concentrations of inflammatory cytokines. The ability 
of n-3 PUFAs to decrease production of inflammatory cytokines and eicosanoids suggests that fish oil might be a useful agent to aid the control of endotoxemia and the socalled systemic inflammatory response syndrome.

Fish oil feeding to rats resulted in a markedly altered profile of post-endotoxin circulating eicosanoids (e.g., less $\mathrm{PGE}_{2}, \mathrm{TXB}_{2}$ and 6-keto-PGF $\left.{ }_{1 \alpha}\right)(11,23)$ and of eicosanoid generation by isolated alveolar macrophages $\left(40 \%\right.$ less $\mathrm{LTB}_{4}$ and over 10 times more $\mathrm{LTB}_{5}$ ) (11). Mice fed fish oil and then injected with endotoxin had significantly lower plasma TNF- $\alpha$, IL-1 1 and IL-6 concentrations than mice fed safflower oil (24). Fish oil-containing parenteral nutrition significantly decreased serum TNF- $\alpha$, IL- 6 and IL8 concentrations in burned rats (25). In a study on rats subjected to cecal ligation and puncture, the concentrations of TNF- $\alpha$, IL$1 \beta$ and IL- 6 in peritoneal lavage fluid were lower by 70,70 and $50 \%$, respectively, in rats receiving parenteral infusion of fish oil than in those receiving safflower oil (26).

Fish oil feeding in guinea pigs or rats or fish oil infusion in guinea pigs enhanced survival following endotoxin challenge (2729). Fish oil feeding decreased endotoxininduced metabolic perturbations (fever, acidosis, hypotension, anorexia, weight loss) in guinea pigs and/or rats (29-34). Fish oil (or EPA) improved heart and lung function and decreased lung edema in endotoxic rats $(11,35,36)$ and pigs $(37-39)$. Some studies report that dietary fish oil does not attenuate endotoxin-induced hepatic injury, despite various metabolic improvements $(29,40,41)$.

Total parenteral nutrition using fish oil as the lipid source was found to prevent the endotoxin-induced reduction in blood flow to the gut and to reduce the number of viable bacteria in mesenteric lymph nodes and liver following exposure to live bacteria (42). Fish oil did not, however, decrease bacterial trans- location across the gut and the authors concluded that fish oil must have improved bacterial killing. Fish oil administration prior to exposure to live pathogens decreased mortality of rats compared with vegetable oil $(43,44)$. These studies did not measure inflammatory cytokine levels but they showed that $\mathrm{PGE}_{2}$ levels were decreased by fish oil $(43,44)$. More recently, fish oil infusion after induction of sepsis by cecal ligation and puncture in rats was shown to decrease mortality (and $\mathrm{PGE}_{2}$ production) compared with vegetable oil (45). Intragastric administration of fish oil into chow-fed rats prior to cecal ligation and puncture improved survival of rats compared with vegetable oil or saline infusion (46).

\section{Studies of fish oil-containing parenteral nutrition in surgical patients}

An understanding of the inflammatory changes occurring during sepsis and of the anti-inflammatory effects of fish oil, combined with the outcome of the animal experiments outlined above, has prompted the development of emulsions containing fish oil designed for use in critically ill patients (see 47 for a review).

Parenteral nutrition supplemented with fish oil has been shown to affect circulating inflammatory mediator concentrations and/ or the capacity of leukocytes to produce inflammatory mediators in various patient groups. For example, infusion of a fish oilcontaining lipid emulsion into postoperative patients resulted in an increased capacity of stimulated blood leukocytes to generate $\mathrm{LTC}_{4}$ at day 6 postoperation (48). Fish oil infusion was also found to decrease the production of $\mathrm{TXB}_{2}$ and to increase the production of TXA by platelets from patients postsurgery (49). In another study, patients received either an MCT-long chain triacylglycerol mix or this 
mix also containing fish oil for 5 days postsurgery (50). Patients in the fish oil group received $3 \mathrm{~g}$ (days 1 and 2 ) and $6 \mathrm{~g}$ (days 3 , 4 and 5) n-3 PUFAs/day. Neutrophils from patients infused with fish oil produced less $\mathrm{LTB}_{4}$ and significantly more $\mathrm{LTB}_{5}$ at postoperative days 6 and 10. Plasma TNF- $\alpha$ (days 6 and 10) and IL-6 (day 10) concentrations were lower in patients receiving fish oil (50). This study did not report clinical outcomes. Recently, the results of three further studies with parenteral fish oil administration have become available (51-53). In the first of these, patients received total parenteral nutrition that included an $8 \%$ soybean oil plus $2 \%$ fish oil emulsion (controls received a $10 \%$ soybean oil emulsion) for 5 days postsurgery (51). Patients in the fish oil group received $0.2 \mathrm{~g}$ fish oil $/ \mathrm{kg}$ body weight per day; it is not clear from the fatty acid compositions of the emulsions provided exactly how much n-3 PUFAs this would equate to. There were no differences between groups with respect to the concentrations and/or activities of a range of coagulation factors, the function of platelets, and complications. Another study compared the effects of lipid emulsions on lymphocyte functions in patients following large bowel surgery (52). Patients received lipid-free total parenteral nutrition or parenteral nutrition including $10 \%$ soybean oil or $8.3 \%$ soybean oil plus $1.7 \%$ fish oil for 5 days postoperatively. The amount of fish oil provided was $0.1 \mathrm{~g} / \mathrm{kg}$ body weight for the first day and $0.2 \mathrm{~g} / \mathrm{kg}$ body weight for days 2 to 5 ; this equated to about $3 \mathrm{~g}$ long chain n-3 PUFAs/day based on a $70 \mathrm{~kg}$ body weight. Blood lymphocyte numbers and functions were measured before surgery and at days 3 and 6 postsurgery. Although surgery affected blood lymphocyte numbers, there were no differences between the groups with respect to numbers of total lymphocytes, T cells, B cells, CD4+ lymphocytes, CD8+ lymphocytes or natural killer cells in the circulation at any of the time points. Furthermore, there were no differences between the groups with respect to lymphocyte proliferation stimulated by a mitogen. In contrast, ex vivo IL-2 production was increased in the fish oil group, and the postsurgery decline in ex vivo IFN- $\gamma$ production was prevented by fish oil (52). Thus, this study indicates that, in these patients, parenteral fish oil does not impair cell-mediated immune responses, and may even preserve or improve them. Weiss et al. (53) infused $10 \%$ fish oil on the day before surgery and on days 1 to 5 postsurgery into patients undergoing abdominal surgery. On postoperative days 4 and 5 the patients also received standard total parenteral nutrition, which included $50 \mathrm{~g}$ fat/day. Control patients received the same regimen apart from the fish oil infusions. White cell count, the serum concentrations of $\mathrm{C}$-reactive protein, and TNF- $\alpha$ and neutrophil respiratory burst activity were not different between groups, although they were affected by surgery. TNF$\alpha$ production by endotoxin-stimulated whole blood tended to be lower at postoperative day 5 in the fish oil group, but the difference did not reach significance. Serum IL-6 concentration was significantly lower in the fish oil group at postsurgery days 0,1 and 3 . In contrast, monocyte expression of human leukocyte antigen-DR, which is involved in antigen presentation, was preserved in the fish oil group but declined at postsurgery days 3 and 5 in the control group (53). No differences in infection rates or mortality between the groups were observed. Postoperative stay in the intensive care unit tended to be shorter in the fish oil group (4.1 vs 9.1 days) as did total hospital stay (17.8 vs 23.5 days). Postoperative stay on the medical wards was significantly shorter in the fish oil group (53). These studies indicate the potential for significant modification of the inflammatory and immune changes induced by surgery by infusion of n-3 PUFAs in the form of fish oil. However, larger studies are 
needed to evaluate the effects on complication rates, hospital stay and mortality.

\section{Studies of fish oil-containing enteral nutrition in surgical or critically ill patients}

A large number of studies incorporating fish oil into enteral formulae have been conducted in intensive care and surgical patients. The majority of these trials have used the commercially available product IMPACT ${ }^{\circledR}$ which contains arginine, nucleotides and n-3 PUFA. n-3 PUFAs make up about $10 \%$ of the fatty acids in IMPACT ${ }^{\circledR}$, which contains about $3 \mathrm{~g} \mathrm{n}-3$ PUFAs per litre. Meta-analyses of studies using IMPACT $^{\circledR}$ or Immun-Aid ${ }^{\circledR}$ (also rich in arginine, RNA and n-3 PUFA) have been performed (54-56). These analyses confirmed significant reductions in infection rate, number of ventilator days and length of hospital stay, but not in overall mortality. Table 2 lists the studies of enteral nutrition involving n-3 PUFAs that have reported immune and/ or inflammatory outcomes. A number of studies have reported circulating lymphocyte numbers and subsets and circulating immunoglobulin concentrations and most report little difference in these compared with the control group. Some studies have reported aspects of immune function such as phagocytosis, respiratory burst, lymphocyte proliferation, human leukocyte antigen-DR expression on monocytes and cytokine production; several of these studies report some significant improvements in these functions in patients given IMPACT ${ }^{\circledR}$ compared with the control group. The most frequently reported outcomes of these types are those related to inflammatory cytokines, which is perhaps not surprising given their role in progression to systemic inflammatory response syndrome. One study has reported lower spontaneous production of TNF- $\alpha$ and IL- 6 by diluted whole blood after several days of IMPACT ${ }^{\circledR}$ administration (62). Several studies report lower circulating concentrations of IL- 6 in the IMPACT ${ }^{\circledR}$ group, while there are also reports of lower circulating TNF- $\alpha$ concentrations (see Table 2 for references). Although many of these observations fit with the effects of n-3 PUFA that might be predicted based upon studies in cell culture, animals and healthy humans, and could be used as evidence of the efficacy of n-3 PUFA in the trauma and postsurgery settings, the complex nature of the formulae prevents such a clear interpretation. The effects could be due to any one of the specified nutrients (i.e., arginine, RNA, n-3 PUFA) or to the combination of these nutrients. Indeed, the positive outcomes from the use of IMPACT ${ }^{\circledR}$ and Immun-Aid ${ }^{\circledR}$ have often been used as evidence for the benefit of arginine in these settings.

One other recent trial performed in patients with moderate and severe acute respiratory distress syndrome has used an enteral preparation apparently differing only in lipid source from the control (32\% canola oil + $25 \%$ MCT $+20 \%$ borage oil $+20 \%$ fish oil + $3 \%$ soy lecithin vs $97 \%$ corn oil $+3 \%$ soy lecithin) (70). However, in addition to the difference in fatty acid composition between the formulae, the n-3 PUFA-rich formula contained more vitamin $\mathrm{C}$ and $\mathrm{E}$ than the control and contained B-carotene, taurine and carnitine, which the control did not. Patients received about $7 \mathrm{~g}$ EPA, $3 \mathrm{~g}$ DHA, 6 g $\gamma$-linolenic acid, $1.1 \mathrm{~g}$ vitamin $\mathrm{C}, 400 \mathrm{IU}$ vitamin $\mathrm{E}$ and $6.6 \mathrm{mg} ß$-carotene per day for up to 7 days. By 4 days the numbers of leukocytes and neutrophils in the alveolar fluid had significantly declined in the fish oil $+\gamma$-linolenic acid group and were lower than in the control group. Furthermore, arterial oxygenation and gas exchange were improved in the treatment group. Patients in the treatment group had a decreased requirement for supplemental oxygen, reduced time on ventilation support, and shorter length of 
Table 2. Summary of studies employing enteral nutrition including fish oil that have reported immune or inflammatory outcomes.

\begin{tabular}{|c|c|c|c|c|c|}
\hline Ref. & Type of patients & Formula studied & Immune/inflammatory outcomes & $\begin{array}{l}\text { Effects of formula with fish } \\
\text { oil on immune/inflammatory } \\
\text { outcomes }\end{array}$ & Comments on other outcomes \\
\hline 57 & $\begin{array}{l}\text { Burns (av. } 40 \% \\
\text { BSA) }\end{array}$ & $\begin{array}{l}\text { 50:50 Fish oil:safflower } \\
\text { oil vs 50:40:10 MCT: } \\
\text { corn oil:soybean oil vs } \\
\text { 70:30 soybean oil:MCT }\end{array}$ & $\begin{array}{l}\text { Lymphocyte count } \\
\text { Bacterial killing by neutrophilis }\end{array}$ & $\begin{array}{l}\text { None } \\
\text { None }\end{array}$ & $\begin{array}{l}\downarrow \text { wound infections, } \\
\text { infectious episodes and } \\
\text { length of hospital stay } \\
\text { (expressed as \% of original } \\
\text { BSA burn) in fish oil group } \\
\text { No effect on mortality }\end{array}$ \\
\hline 58 & $\begin{array}{l}\text { ICU (trauma, } \\
\text { surgery, sepsis) }\end{array}$ & IMPACT ${ }^{\circledR}$ vs Standard & Lymphocyte proliferation & $\uparrow$ at days 3 and 7 & $\begin{array}{l}\text { No effect on length of } \\
\text { hospital stay or mortality }\end{array}$ \\
\hline 59 & Cancer surgery & IMPACT ${ }^{\circledR}$ vs Standard & $\begin{array}{l}\text { Complement C3 } \\
\text { Circulating lymphocyte and } \\
\text { subset numbers } \\
\text { HLA-DR expression on } \\
\text { monocytes } \\
\text { Lymphocyte proliferation }\end{array}$ & $\begin{array}{l}\text { None } \\
\text { None } \\
\text { None } \\
\uparrow \text { at day } 7\end{array}$ & $\begin{array}{l}\downarrow \text { No. of patients with } \\
\text { infectious/healing, } \\
\text { complications in IMPACT } \\
\text { group } \\
\text { No effect on mortality }\end{array}$ \\
\hline 60 & Cancer surgery & IMPACT ${ }^{\circledR}$ vs Standard & $\begin{array}{l}\text { Circulating IgG and IgM } \\
\text { Circulating lymphocyte subsets } \\
\text { IFN-y production by stimulated } \\
\text { lymphocytes }\end{array}$ & $\begin{array}{l}\operatorname{lgG} \uparrow \text { at day } 16 \text {; } \lg M \uparrow \text { at } \\
\text { days } 7 \text { and } 10 \\
\text { Number of } T \text { cells, helper } \\
T \text { cells and } B \text { cells } \uparrow \text { at } \\
\text { days } 7,10 \text { and } 16 \\
\uparrow \text { at day } 16\end{array}$ & \\
\hline 61 & Cancer surgery & IMPACT ${ }^{\circledR}$ vs Standard & $\begin{array}{l}\mathrm{PGE}_{2} \text { production by endotoxin- } \\
\text { stimulated cells }\end{array}$ & $\begin{array}{l}\text { Time-dependent } \downarrow \text { by up to } \\
60 \%\end{array}$ & $\begin{array}{l}\downarrow \text { infections and length of } \\
\text { hospital stay }\end{array}$ \\
\hline 62 & Cancer surgery & IMPACT ${ }^{\circledR}$ vs Standard & $\begin{array}{l}\text { Spontaneous or mitogen- } \\
\text { stimulated production of: } \\
\text { IL-1 } \alpha \\
\text { IL-1ß, IL-2 } \\
\text { IL-2R } \\
\text { IL-6 } \\
\text { TNF- } \alpha\end{array}$ & $\begin{array}{l}\text { None } \\
\uparrow \text { at day } 16 \text { (+ mitogen) } \\
\uparrow \text { at days } 7 \text { and } 10 \text { (+ mitogen) } \\
\downarrow \text { at days } 3 \text { and } 7 \text { (spontaneous } \\
\downarrow \text { at days } 7 \text { (spontaneous) }\end{array}$ & \\
\hline 63 & Cancer surgery & $\begin{array}{l}\text { IMPACT }{ }^{\circledR} \text { vs Standard } \\
\text { vs low-fat TPN }\end{array}$ & $\begin{array}{l}\text { Circulating IgA, IgG, IgM } \\
\text { Circulating complement C3 } \\
\text { Circulating TNF- } \alpha, \text { IL-1, } \\
\text { IL-6, sIL-2R } \\
\text { Leukocyte counts and } \\
\text { subset numbers } \\
\text { Phagocytosis by monocytes } \\
\text { and neutrophils }\end{array}$ & $\begin{array}{l}\text { None } \\
\text { None } \\
\text { None } \\
\text { Some } \\
\uparrow \text { at days 8-10 for } \\
\text { monocytes }\end{array}$ & \\
\hline 64 & Cancer surgery & $\begin{array}{l}\text { IMPACT }{ }^{\circledR} \text { vs Standard } \\
\text { vs TPN }\end{array}$ & $\begin{array}{l}\text { Circulating IgA, IgG, IgM } \\
\text { Circulating complement C3 } \\
\text { Circulating sIL-2R } \\
\text { Circulating IL-6 } \\
\text { Circulating lymphocyte and } \\
\text { subset numbers } \\
\text { Phagocytosis by monocytes } \\
\text { DTH response }\end{array}$ & $\begin{array}{l}\text { None } \\
\text { None } \\
\uparrow \text { at day } 8 \\
\downarrow \text { at day } 8 \\
\text { None } \\
\uparrow \text { at days } 4 \text { and } 8 \\
\uparrow \text { at day } 8\end{array}$ & $\begin{array}{l}\text { No effect on } \% \text { infected } \\
\text { patients but } \downarrow \text { infection score } \\
\downarrow \text { length of hospital stay }\end{array}$ \\
\hline
\end{tabular}


Table 2 continued.

\begin{tabular}{|c|c|c|c|c|c|}
\hline Ref. & Type of patients & Formula studied & Immune/inflammatory outcomes & $\begin{array}{l}\text { Effects of formula with fish } \\
\text { oil on immune/inflammatory } \\
\text { outcomes }\end{array}$ & Comments on other outcome \\
\hline 65 & Trauma & IMPACT ${ }^{\circledR}$ vs Standard & $\begin{array}{l}\text { Circulating C-reactive protein } \\
\text { Circulating lymphocyte and } \\
\text { subset numbers } \\
\text { IL-2R expression on lymphocytes } \\
\text { HLA-DR expression on monocytes }\end{array}$ & $\begin{array}{l}\downarrow \text { at day } 4 \\
\text { None } \\
\text { None } \\
\uparrow \text { at day } 7\end{array}$ & $\begin{array}{l}\text { No effects on infection rate, } \\
\text { length of hospital or ICU } \\
\text { stay, or mortality }\end{array}$ \\
\hline 66 & Cancer surgery & IMPACT ${ }^{\circledR}$ vs Standard & $\begin{array}{l}\text { Circulating C-reactive protein } \\
\text { Circulating IL-6 }\end{array}$ & $\begin{array}{l}\downarrow \text { at days } 1 \text { and } 8 \\
\downarrow \text { at days } 1 \text { and } 8\end{array}$ & $\begin{array}{l}\downarrow \text { number of antibiotic days, } \\
\% \text { infected patients and } \\
\text { length of hospital stay }\end{array}$ \\
\hline 67 & Cancer surgery & IMPACT ${ }^{\circledR}$ vs Standard & $\begin{array}{l}\text { Circulating IgA, IgG, IgM } \\
\text { Circulating complement C3 } \\
\text { Circulating sIL-2R } \\
\text { Circulating IL-6 } \\
\text { Circulating SIL-1R } \\
\text { DTH response }\end{array}$ & $\begin{array}{l}\text { None } \\
\text { None } \\
\uparrow \text { at days 1,4 and 8 } \\
\downarrow \text { at days } 1,4 \text { and 8 } \\
\downarrow \text { at days } 4 \text { and 8 } \\
\uparrow \text { at days 1,4 and 8 }\end{array}$ & \\
\hline 68 & $\begin{array}{l}\text { Cardiac bypass } \\
\text { surgery }\end{array}$ & $\begin{array}{l}\text { IMPACT }^{\circledR} \text { vs Standard } \\
\text { (from } \geq 5 \text { days } \\
\text { preoperatively) }\end{array}$ & $\begin{array}{l}\text { Circulating IL-6 } \\
\text { Monocyte HLA-DR expression } \\
\text { DTH response }\end{array}$ & $\begin{array}{l}\downarrow \text { immediately before and } \\
\text { during surgery } \\
\text { None } \\
\uparrow \text { at admission }\end{array}$ & $\begin{array}{l}\text { No effect on time on } \\
\text { ventilator, or length of ICU } \\
\text { or hospital stay }\end{array}$ \\
\hline 69 & Cancer surgery & Nutrison ${ }^{\circledR}$ vs Standard & $\begin{array}{l}\text { Circulating C-reactive protein } \\
\text { Circulating lymphocyte and } \\
\text { subset numbers } \\
\text { Circulating IL-1, IL-2 } \\
\text { Circulating TNF- } \alpha, \text { IL- } 6 \\
\text { Circulating PGE } 2 \\
\text { Neutrophil phagocytosis } \\
\text { Neutrophil respiratory burst }\end{array}$ & $\begin{array}{l}\downarrow \text { at day } 8 \\
\uparrow \text { total lymphocytes and \% } \\
\text { T cells, T helper cells, NK } \\
\text { cells at day } 8 \\
\downarrow \text { cytotoxic T cells at day } 8 \\
\text { None } \\
\downarrow \text { at day } 8 \\
\text { None } \\
\uparrow \\
\uparrow\end{array}$ & \\
\hline
\end{tabular}

BSA, body surface area; DTH, delayed-type hypersensitivity; HLA, human leukocyte antigen; ICU, intensive care unit; IFN, interferon; Ig, immunoglobulin; IL, interleukin; MCT, medium chain triglyceride; NK, natural killer; PG, prostaglandin; R, receptor; TNF, tumour necrosis factor; TPN, total parenteral nutrition.

intensive care unit stay $(12.8 \pm 1.1$ vs $17.5 \pm$ 1.7 days). Total length of hospital stay also tended to be shorter $(29.4 \pm 2.6$ vs $34.6 \pm 3.3$ days). Fewer patients in the treatment group developed new organ failure (4/51 vs 13/47). Mortality was $19 \%$ in the control group and $12 \%$ in the treatment group, but this was not a significant difference. Nevertheless, this study suggests efficacy of n-3 PUFAs (in combination with $\gamma$-linolenic acid, MCT, antioxidant vitamins, taurine and carnitine) in this group of patients.

\section{Concluding statement}

Inflammation is a normal part of host defence. However, excessive or inappropriate inflammation is a component of a range of acute and chronic human diseases, including the systemic inflammatory response to surgery, trauma, injury and infection. Inflammation is characterised by the production of inflammatory cytokines, ARA-derived eicosanoids, other inflammatory mediators (e.g., platelet-activating factor) and 
adhesion molecules. n-3 PUFAs decrease the production of inflammatory cytokines and eicosanoids. They act both directly (e.g., by replacing ARA as an eicosanoid substrate and inhibiting ARA metabolism) and indirectly (e.g., by altering the expression of inflammatory genes through effects on transcription factor activation; see 18,19). Thus, n-3 PUFAs are potentially potent anti-inflammatory agents. As such, they may be of therapeutic use in a variety of acute and chronic inflammatory settings. Evidence of their clinical efficacy is strong in some settings (e.g., in rheumatoid arthritis) but generally weak in others (e.g., in asthma; see 19). An emerging application is in surgical or critically ill patients. At the levels that have been used parenterally or enterally they do not appear to exert any adverse effects. Parenteral nutrition including n-3 PUFAs appears to preserve immune function better than standard total parenteral nutrition and appears to partly prevent some aspects of the inflammatory response. There may be some clinical benefit from these effects. n-3 PUFAs are a component of enteral formulae (e.g., IMPACT $^{\circledR}$, Immun-Aid ${ }^{\circledR}$, Nutrison ${ }^{\circledR}$ ) that have been examined in a number of clinical trials. There is a lack of consistency in many of the immune and inflammatory outcomes from these studies. However, several studies do report maintenance of immune function and a decreased capacity for production of some inflammatory cytokines. Unlike the studies using parenteral nutrition, it is not possible to ascribe these effects to n-3 PUFAs, since the formulae contain several other "immunonutrients". Nevertheless, these studies support the inclusion of n-3 PUFAs in such formulae.

\section{References}

1. Lewis RA, Austen KF \& Soberman RJ (1990). Leukotrienes and other products of the 5-lipoxygenase pathway: Biochemistry and relation to pathobiology in human diseases. New England Journal of Medicine, 323: 645-655.

2. Tilley SL, Coffman TM \& Koller BH (2001). Mixed messages: modulation of inflammation and immune responses by prostaglandins and thromboxanes. Journal of Clinical Investigation, 108: 15-23.

3. Harris SG, Padilla J, Koumas L, Ray D \& Phipps RP (2002). Prostaglandins as modulators of immunity. Trends in Immunology, 23: 144-150.

4. Levy BD, Clish CB, Schmidt B, Gronert K \& Serhan CN (2001). Lipid mediator class switching during acute inflammation: signals in resolution. Nature Immunology, 2: 612-619.

5. Cohen IT, Meunier KM \& Hirsh MP (1989). Effects of lipid emulsion on pulmonary function in infants. In: Kinney JM \& Borum PR (Editors), Perspectives in Clinical Nutrition. Urban \& Schwarzenberg, Baltimore, 415-427.

6. Calder PC, Sherrington EJ, Askanazi J \& Newsholme EA (1994). Inhibition of lymphocyte proliferation in vitro by two lipid emulsions with different fatty acid compositions. Clinical Nutrition, 13: 69-74.

7. Obata T, Nagakura T, Masaki T, Maekawa K \& Yamashita K (1999). Eicosapentaenoic acid inhibits prostaglandin $\mathrm{D} 2$ generation by inhibiting cyclo-oxygenase-2 in cultured human mast cells. Clinical and Experimental Allergy, 29: 1129-1135.

8. Lee TH, Hoover RL, Williams JD, Sperling RI, Ravalese J, Spur BW, Robinson DR, Corey EJ, Lewis RA \& Austen KF (1985). Effects of dietary enrichment with eicosapentaenoic acid and docosahexaenoic acid on in vitro neutrophil and monocyte leukotriene generation and neutrophil function. New England Journal of Medicine, 312:
1217-1224.

9. Sperling RI, Benincaso Al, Knoell CT, Larkin JK, Austen KF \& Robinson DR (1993). Dietary $\omega-3$ polyunsaturated fatty acids inhibit phosphoinositide formation and chemotaxis in neutrophils. Journal of Clinical Investigation, 91: 651-660.

10. Von Schacky C, Kiefl R, Jendraschak E \& Kaminski WE (1993). n-3 Fatty acids and cysteinyl-leukotriene formation in humans in vitro, ex vivo and in vivo. Journal of Laboratory and Clinical Medicine, 121: 302-309.

11. Sane S, Baba M, Kusano $C$, Shirao K, Andoh T, Kamada T \& Aikou T (2000). Eicosapentaenoic acid reduces pulmonary edema in endotoxemic rats. Journal of Surgical Research, 93: 21-27.

12. Lee TH, Mencia-Huerta JM, Shih C, Corey EJ, Lewis RA \& Austen KF (1984). Characterization and biologic properties of 5,12-dihydroxy derivatives of eicosapentaenoic acid, including leukotriene-B5 and the double lipoxygenase product. Journal of Biological Chemistry, 259: 2383-2389.

13. Goldman DW, Pickett WC \& Goetzl EJ (1983). Human neutrophil chemotactic and degranulating activities of leukotriene B5 (LTB5) derived from eicosapentaenoic acid. Biochemical and Biophysical Research Communications, 117: 282-288.

14. Serhan CN, Clish CB, Brannon J, Colgan SP, Gronert K \& Chiang N (2000). Anti-microinflammatory lipid signals generated from dietary n-3 fatty acids via cyclooxygenase-2 and transcellular processing: a novel mechanism for NSAID and n-3 PUFA therapeutic actions. Journal of Physiology and Pharmacology, 51: 643-654.

15. Grimminger F, Wahn H, Mayer K, Kiss L, Walmrath D \& Seeger W (1997). Impact of arachidonic acid versus eicosapentaenoic acid on exotoxin-induced lung vascular leakage - relation to 4-series versus 
5-series leukotriene generation. American Journal of Respiratory and Critical Care Medicine, 155: 513-519.

16. Grimminger F, Mayer K, Kiss L, Wahn H, Walmrath D, Bahkdi S \& Seeger W (1997). Synthesis of 4-series and 5-series leukotrienes in the lung microvasculature challenged with Escherichia coli hemolysin: critical dependence on exogenous free fatty acid supply. American Journal of Respiratory Cell and Molecular Biology, 16: 317-324.

17. Breil I, Koch T, Heller A, Schlotzer E, Grunert A, van Ackern K \& Neuhof $H$ (1996). Alteration of $n-3$ fatty acid composition in lung tissue after short-term infusion of fish oil emulsion attenuates inflammatory vascular reaction. Critical Care Medicine, 24: 1893-1902.

18. Miles EA \& Calder PC (1998). Modulation of immune function by dietary fatty acids. Proceedings of the Nutrition Society, 57: 277292.

19. Calder PC (2002). Dietary modification of inflammation with lipids. Proceedings of the Nutrition Society, 61: 345-358.

20. Priante G, Bordin L, Musacchio E, Clari G \& Baggio B (2002). Fatty acids and cytokine mRNA expression in human osteoblastic cells: a specific effect of arachidonic acid. Clinical Science, 102: 403-409.

21. Curtis $C L$, Hughes $C E$, Flannery $C R$, Little $C B$, Harwood JL \& Caterson B (2000). n-3 Fatty acids specifically modulate catabolic factors involved in articular cartilage degradation. Journal of Biological Chemistry, 275: 721-724.

22. Curtis CL, Rees SG, Little CB, Flannery CR, Hughes CE, Wilson C, Dent CM, Otterness IG, Harwood JL \& Caterson B (2002). Pathologic indicators of degradation and inflammation in human osteoarthritic cartilage are abrogated by exposure to $n-3$ fatty acids. Arthritis and Rheumatism, 46: 1544-1553.

23. Utsunomiya T, Chavali SR, Zhong WW \& Forse RA (1994). Effects of continuous tube feeding of dietary fat emulsions on eicosanoid production and on fatty acid composition during an acute septic shock in rats. Biochimica et Biophysica Acta, 1214: 333-339.

24. Sadeghi S, Wallace FA \& Calder PC (1999). Dietary lipids modify the cytokine response to bacterial lipopolysaccharide in mice. Immunology, 96: 404-410.

25. Hayashi N, Tashiro T, Yamamori H et al. (1998). Effects of intravenous omega-3 and omega- 6 fat emulsion on cytokine production and delayed type hypersensitivity in burned rats receiving total parenteral nutrition. Journal of Parenteral and Enteral Nutrition, 22: 363-367.

26. Chao CY, Yeh SL, Lin MT \& Chen WJ (2000). Effects of parenteral infusion with fish-oil or safflower-oil emulsion on hepatic lipids, plasma amino acids, and inflammatory mediators in septic rats. Nutrition, 16: 284-288.

27. Mascioli EA, Leader L, Flores E, Trimbo S, Bistrian B \& Blackburn G (1988). Enhanced survival to endotoxin in guinea pigs fed iv fish oil emulsion. Lipids, 23: 623-625.

28. Mascioli EA, Iwasa Y, Trimbo S, Leader L, Bistrian BR \& Blackburn GL (1989). Endotoxin challenge after menhaden oil diet: effects on survival of guinea pigs. American Journal of Clinical Nutrition, 49: 277-282.

29. Murray MJ, Kanazi G, Moukabary K, Tazelaar HD \& DeMichele SJ (2000). Effects of eicosapentaenoic and $\gamma$-linolenic acids (dietary lipids) on pulmonary surfactant composition and function during porcine endotoxemia. Chest, 117: 1720-1727.

30. Hellerstein MK, Meydani SN, Meydani M, Wu K \& Dinarello CA (1989). Interleukin-1-induced anorexia in the rat: influence of prostaglandins. Journal of Clinical Investigation, 84: 228-235.

31. Pomposelli J, Mascioli EA, Bistrian BR, Lopes SM \& Blackburn GL (1990). Attenuation of the febrile response in guinea pigs by fish oil enriched diets. Journal of Parenteral and Enteral Nutrition, 13: 136-
140.

32. Pomposelli JJ, Flores EA, Blackburn G, Zeisel SH \& Bistrian BR (1991). Diets enriched with n-3 fatty acids ameliorate lactic acidosis by improving endotoxin-induced tissue hypoperfusion in guinea pigs. Annals of Surgery, 213: 166-176.

33. Teo TC, Selleck KM, Wan JMF, Pomposelli JJ, Babayan VK, Blackburn GL \& Bistrian BR (1991). Long-term feeding with structured lipid composed of medium-chain and n-3 fatty acids ameliorates endotoxic shock in guinea pigs. Metabolism, 40: 1152-1159.

34. Mulrooney HM \& Grimble RF (1994). Influence of butter and of corn, coconut and fish oils on the effects of recombinant human tumour necrosis factor- $\alpha$ in rats. Clinical Science, 84: 105-112.

35. Mancuso P, Whelan J, DeMichele SJ, Snider CC, Guszcza JA \& Karlstad MD (1997). Dietary fish oil and fish and borage oil suppress intrapulmonary proinflammatory eicosanoid biosynthesis and attenuate pulmonary neutrophil accumulation in endotoxic rats. Critical Care Medicine, 25: 1198-1206.

36. Mancuso P, Whelan J, DeMichele SJ, Snider CC, Guszcza JA, Claycombe KJ, Smith GT, Gregory TJ \& Karlstad MD (1997). Effects of eicosapentaenoic and gamma-linolenic acid on lung permeability and alveolar macrophage eicosanoid synthesis in endotoxic rats. Critical Care Medicine, 25: 523-532.

37. Murray MJ, Svinger BA, Holman RT \& Yaksh TL (1991). Effects of a fish oil diet on pig's cardiopulmonary response to bacteremia. Journal of Parenteral and Enteral Nutrition, 15: 152-158.

38. Murray MJ, Svinger BA, Yaksh TL \& Holman RT (1993). Effects of endotoxin on pigs prefed omega-3 vs omega- 6 fatty acids-enriched diets. American Journal of Physiology, 265: E920-E927.

39. Murray MJ, Kumar M, Gregory TJ, Banks PL, Tazelaar HD \& DeMichele SJ (1995). Select dietary fatty acids attenuate cardiopulmonary dysfunction during acute lung injury in pigs. American Journal of Physiology, 269: H2090-H2097.

40. Lo CJ, Terasaki M, Garcia R \& Helton S (1997). Fish oil-supplemented feeding does not attenuate warm liver ischemia and reperfusion injury in the rat. Journal of Surgical Research, 71: 54-60.

41. Vollmar B, Bauer C \& Menger MD (2002). n-3 Polyunsaturated fatty acid-enriched diet does not protect from liver injury but attenuates mortality rate in a rat model of systemic endotoxemia. Critical Care Medicine, 30: 1091-1098.

42. Pscheidl E, Schywalsky M, Tschaikowsky K \& Boke-Prols T (2000). Fish oil-supplemented parenteral diets normalize splanchnic blood flow and improve killing of translocated bacteria in a low-dose endotoxin rat model. Critical Care Medicine, 28: 1489-1496.

43. Barton RG, Wells CL, Carlson A, Singh R, Sullivan JJ \& Cerra FB (1991). Dietary omega-3 fatty acids decrease mortality and Kupffer cell prostaglandin $\mathrm{E}_{2}$ production in a rat model of chronic sepsis. Journal of Trauma, 31: 768-774.

44. Rayon JI, Carver JD, Wyble LE, Wiener D, Dickey SS, Benford VJ, Chen LT \& Lim DV (1997). The fatty acid composition of maternal diet affects lung prostaglandin $E_{2}$ levels and survival from group $B$ streptococcal sepsis in neonatal rat pups. Journal of Nutrition, 127: 1989-1992.

45. Lanza-Jacoby S, Flynn JT \& Miller S (2001). Parenteral supplementation with a fish oil emulsion prolongs survival and improves lymphocyte function during sepsis. Nutrition, 17: 112-116.

46. Johnson JA, Griswold JA, Muakkassa FF, Meyer AA, Maier RV, Chaudry IH \& Cerra F (1993). Essential fatty acids influence survival in stress. Journal of Trauma, 35: 128-131.

47. Furst P \& Kuhn KS (2000). Fish oil emulsions: what benefits can they bring? Clinical Nutrition, 19: 7-14.

48. Morlion BJ, Torwesten E, Lessire A, Sturm G, Peskar BM, Furst P \& 
Puchstein C (1996). The effect of parenteral fish oil on leukocyte membrane fatty acid composition and leukotriene-synthesizing capacity in postoperative trauma. Metabolism, 45: 1208-1213.

49. Roulet M, Frascarolo P, Pilet M \& Capuis G (1997). Effects of intravenously infused fish oil on platelet fatty acid phospholipid composition and on platelet function in postoperative trauma. Journal of Parenteral and Enteral Nutrition, 21: 296-301.

50. Wachtler P, Konig W, Senkal M, Kemen M \& Koller M (1997). Influence of a total parenteral nutrition enriched with $\omega-3$ fatty acids on leukotriene synthesis of peripheral leukocytes and systemic cytokine levels in patients with major surgery. Journal of Trauma, 42: 191-198.

51. Heller AR, Fischer S, Rossel T, Geiger S, Siegert G, Ragaller M, Zimmermann T \& Koch T (2002). Impact of n-3 fatty acid supplemented parenteral nutrition on haemostasis patterns after major abdominal surgery. British Journal of Nutrition, 87: S95-S101.

52. Schauder P, Rohn U, Schafer G, Korff G \& Schenk H-D (2002). Impact of fish oil enriched total parenteral nutrition on DNA synthesis, cytokine release and receptor expression by lymphocytes in the postoperative period. British Journal of Nutrition, 87: S103-S110.

53. Weiss G, Meyer F, Matthies B, Pross M, Koenig W \& Lippert H (2002). Immunomodulation by perioperative administration of $n-3$ fatty acids. British Journal of Nutrition, 87: S89-S94.

54. Heys SD, Walker LG, Smith I \& Eremin O (1999). Enteral nutritional supplementation with key nutrients in patients with critical illness and cancer - a meta-analysis of randomized controlled clinical trials. Annals of Surgery, 229: 467-477.

55. Beale RJ, Bryg DJ \& Bihari DJ (1999). Immunonutrition in the critically ill: a systematic review of clinical outcome. Critical Care Medicine, 27: 2799-2805.

56. Heyland DK, Novak F, Drover JW, Jain A, Su XY \& Suchner U (2001). Should immunonutrition become routine in critically ill patients? A systematic review of the evidence. Journal of the American Medical Association, 286: 944-953.

57. Gottschlich MM, Jenkins M, Warden GD, Baumer T, Havens $P$, Snook JT \& Alexander JW (1990). Differential effects of three enteral dietary regimens on selected outcome variables in burn patients. Journal of Parenteral and Enteral Nutrition, 14: 225-236.

58. Cerra FB, Lehman S, Konstantinides N, Konstantinides F, Shronts EP \& Holman R (1990). Effect of enteral nutrient on in vitro tests of immune function in ICU patients: a preliminary report. Nutrition, 6: 84-87.

59. Daly JM, Lieberman MD, Goldfine J, Shou J, Weintraub F, Rosato EF \& Lavin P (1992). Enteral nutrition with supplemental arginine, RNA, and omega-3 fatty acids in patients after operation: Immunologic, metabolic, and clinical outcome. Surgery, 112: 56-67.

60. Kemen M, Sewnkal M, Homann H-H, Mumme A, Dauphin A-K, Baier J, Windeler J, Neumann H \& Zumtobel V (1995). Early postoperative enteral nutrition with arginine- $\omega-3$ fatty acids and ribonucleic acidsupplemented diet versus placebo in cancer patients: An immunologic evaluation of Impact ${ }^{\circledR}$. Critical Care Medicine, 23: 652-659.

61. Daly JM, Weintraub FN, Shou J, Rosato EF \& Lucia M (1995). Enteral nutrition during multimodality therapy in upper gastrointestinal cancer patients. Annals of Surgery, 221: 327-338.

62. Senkal M, Kemen M, Homann H-H, Eickhoff U, Baier J \& Zumtobel V (1995). Modulation of postoperative immune response by enteral nutrition with a diet enriched with arginine, RNA, and omega-3 fatty acids in patients with upper gastrointestinal cancer. European Journal of Surgery, 161: 115-122.

63. Schilling J, Vranjes N, Fierz W, Joller H, Gyurech D, Ludwig E, Marathias K \& Geroulanos S (1996). Clinical outcome and immunology of postoperative arginine, $\omega-3$ fatty acids, and nucleotide-enriched enteral feeding: a randomized prospective comparison with standard enteral and low calories/low fat iv solutions. Nutrition, 12: 423-429.

64. Braga M, Vignali A, Gianotti L, Cestari A, Profili M \& Di Carlo V (1996). Immune and nutritional effects of early enteral nutrition after major abdominal operations. European Journal of Surgery, 162: 105112.

65. Weimann A, Bastian L, Bischoff WE, Grotz M, Hansel M, Lotz J, Trautwein C, Tusch G, Schlitt HJ \& Regel G (1998). Influence of arginine, omega-3 fatty acids and nucleotide-supplemented enteral support on systemic inflammatory response syndrome and multiple organ failure in patients after severe trauma. Nutrition, 14: 165-172.

66. Braga M, Gianotti L, Radaelli G, Vignali A, Mari G, Gentilini O \& Di Carlo $V$ (1999). Perioperative immunonutrition in patients undergoing cancer surgery. Archives of Surgery, 134: 428-433.

67. Gianotti L, Braga M, Fortis C, Soldini L, Vignali A, Colombo S, Radaelli G \& Di Carlo V (1999). A prospective, randomised clinical trial on perioperative feeding with an arginine-, omega-3 fatty acid-, and RNA-enriched enteral diet: effect on host response and nutritional status. Journal of Parenteral and Enteral Nutrition, 23: 314320.

68. Tepaske R, te Velthuis H, Oudemans-van Straaten M, Heisterkamp SH, van Deventer SJH, Ince C, Eysman L \& Keseciogu J (2001). Effect of preoperative oral immune-enhancing nutritional supplement on patients at risk of infection after cardiac surgery: a randomised placebo-controlled trial. Lancet, 358: 696-701.

69. Wu GH, Zhang YW \& Wu ZH (2001). Modulation of postoperative immune and inflammatory response by immune-enhancing enteral diet in gastrointestinal cancer patients. World Review of Gastroenterology, 7: 357-362.

70. Gadek JE, DeMichele SJ, Karlstad MD et al. (1999). Effect of enteral feeding with eicosapentaenoic acid, $\gamma$-linolenic acid, and antioxidants in patients with acute respiratory distress syndrome. Critical Care Medicine, 27: 1409-1420. 